\title{
DIGLOSIA
}

Volume 1, Nomor 1 (Februari 2018)

\section{PENERAPAN TEKNIK BAGI UNSUR LANGSUNG (BUL) PADA IDENTIFIKASI AFIKS BAHASA DAYAK BENUAQ}

\author{
Widyatmike Gede Mulawarman ${ }^{1, *}$ dan Yeri Iswanto ${ }^{2}$ \\ ${ }^{1,2}$ Pendidikan Bahasa dan Sastra Indonesia, \\ Fakultas Keguruan dan Ilmu Pendidikan, Universitas Mulawarman \\ *Pos-el korespondensi: widyatmikegedemulawarman@yahoo.co.id
}

\begin{abstract}
This study aims to describe the form, function, and meaning of affix attached to the basic form of Benuaq language in Kampung Jengan Danum, Damai District, West Kutai Regency. This research is qualitative research with the technique of data analysis is BUL (Bagi Unsur Langsung) technique. This study was conducted in Kampung Jengan Danum, Damai District, West Kutai Regency. The research data is the entire word affixed spoken of native speakers Benuaq Kampung Jengan Danum. Data collection techniques used are recording techniques, cakap libat semuka technique, and simak cakap technique. The results showed that the Dayak. Benuaq language in Kampung Jengan Danum has three forms affix, that is prefixes, suffixes, and combination of affixes. The prefixes are: $\{b e-\},\{p e-\},\{p e N-\},\{t e-\}$, and $\{N-\}$. The suffixes are: $\{t n\}$. The combination of affixes are: $\{k e-+N-\}$ and $\{$ sek $+N-\}$. The affix converts the categories of adjectives into verbs, verbs into adjectives, nouns into verbs, and nouns into adjectives. The meaning of the affixation of the Benuaq Dayak's basic word is to declare an action, result of, a job, and to say to do work.
\end{abstract}

Keywords: BUL (Bagi Unsur Langsung) technique, affixation of Dayak Benuaq language

\begin{abstract}
ABSTRAK
Penelitian ini bertujuan untuk mendeskripsikan bentuk, fungsi, dan makna afiks yang melekat pada bentuk dasar bahasa Dayak Benuaq di Kampung Jengan Danum, Kecamatan Damai, Kabupaten Kutai Barat. Penelitian ini adalah penelitian kualitatif dengan teknik analisis data menggunakan teknik BUL (Bagi Unsur Langsung). Peneitian ini dilakukan di Kampung Jengan Danum, Kecamatan Damai, Kabupaten Kutai Barat. Data penelitian ini adalah seluruh kata berafiks yang dituturkan dari penutur asli Dayak Benuaq di Kampung Jengan Danum. Teknik pengumpulan data yang digunakan adalah teknik rekam, teknik cakap libat semuka, dan teknik simak cakap. Hasil penelitian diketahui bahwa Bahasa Dayak Benuaq Kampung Jengan Danum diketui memiliki tiga bentuk afiks, yaitu prefiks, sufiks, dan kombinasi afiks. Bentuk prefiks, yaitu: $\{b e-\},\{p e-\},\{p e N-\}$, dan $\{t e-\}$. Bentuk sufiks, yaitu: $\{-t n\}$. Sedangkan kombinasi afiks, yaitu: $\{k e-+N-\}$ dan $\{s e-+N-\}$. Afiks tersebut berfungsi mengubah kategori kata adjektiva menjadi verba, verba menjadi adjetiva, nomina menjadi verba, dan nomina menjadi adjektiva. Makna yang muncul akibat pembubuhan afiks dengan kata dasar ialah menyatakan tindakan, menyatakan akibat, menyatakan pekerjaan, menyatakan sedang melakukan suatu pekerjaan.
\end{abstract}

Kata kunci: Teknik Bagi Unsur Langsung (BUL), afiksasi bahasa Dayak Benuaq 


\section{A. PENDAHULUAN}

Bangsa Indonesia merupakan Negara kepulauan yang terdiri atas lbanyak suku dan bahasa daerah yang tersebar dan digunakan pada daerahnya masing sebut saja Bahasa Jawa, Sunda, Bali, Madura, Dayak dll. terdapat tidak kurang dari 418 bahasa daerah/Nusantara (Banta, 1972:7). Berdasarkan pernyataan tersebut bisa diambil kesimpulan bahwa banyak sekali ragam bahasa daerah/Nusantara yang tersebar. namun sebagian bahasa nusantara yang minoritas sudah punah sedangkan bahasa nusantara yang didukung oleh jumlah penutur yang besar dan sejarah budaya yang cukup tua seperti bahasa Jawa, Sunda, Madura, Melayu, Bugis/Makasar, Minangkabau, Batak, Bali, Aceh dan Sasak yang jumlah penutur lebih dari 1.500 .000 orang.

Bahasa Benuaq merupakan bahasa yang digunakan oleh anak suku Dayak yang berada di wilayah tengah yaitu di wilayah kampung Jengan Danum kecamatan Damai Kabupaten Kutai Barat. Dalam penggunaannya bahasa Benuaq sering digunakan dalam percakapan sehari hari dan digunakan dalam UpacaraUpacara Adat masyarakat Dayak Benuaq. Dalam penelitian ini, Penulis mendeskripsikan salah satu kajian linguistik. Lingusitik adalah ilmu tentang bahasa (Kridalaksana, 1996:128).

Setiap ilmu pengetahuan lazim terdiri atas bidang-bidang keilmuan. linguistik umum juga memliliki tatanan linguistik dari yang terkecil sampai yang terbesar. adapun cabang-cabang linguistik antara lain fonologi, morfologi, sintaksis, semantik, dan pragmatik. Dalam penelitian ini, penulis mendeskripsikan kajian linguistik dari tataran morfologi, yaitu afiks, penulis mengkhususkan pada pokok masalah afiks karena afiks adalah proses yang mengubah leksem menjadi kata yang yang lebih kompleks (Kridalaksana, 1996:128).
Dalam afiks, kita bisa menemukan afiks dari satuan bahasa. kita bisa menemukan proses melekatnya afiks dengan morfem sehingga kita bisa menyimpulkan sebuah teori baru yang dapat memudahkan orang lain mempelajari bahasa tersebut. Maka berdasarkan hal tersebut maka penulis tertarik untuk mendeskripsikan bentukbentuk afiks yang terdapat di dalam bahasa Dayak Benuaq di Kampung Jengan Danum, Kecamatan Damai, Kabupaten Kutai Barat. Penelitian ini juga penulis maksudkan untuk menumbuhkan minat kepada masyarakat suku Dayak Benuaq untuk mencintai dan memelihara bahasa daerahnya sendiri.

\section{B. LANDASAN TEORI}

Chaer (2015:3) menjelaskan bahwa secara etimologi kata morfologi berasal dari kata morf yang berarti 'bentuk' dan kata logi yang berarti 'ilmu'. Jadi secara harfiah kata morfologi dapat diartikan 'ilmu mengenai bentuk'. Di dalam kajian linguistik, morfologi berarti ilmu mengenai bentuk-bentuk dan pembentukan kata', sedangkan di dalam kajian biologi morfologi berarti ilmu mengenai bentuk-bentuk sel-sel tumbuhan atau jasad-jasad hidup'. Memang selain dalam kajian linguistik, dalam kajian biologi pun juga menggunakan istilah morfologi. Kesamaannya adalah sama-sama mengkaji mengenai bentuk.

Ilmu morfologi mempelajari masalah bentuk-bentuk dan pembentukan kata dalam Chaer (2015:3) menjelaskan bahwa semua satuan bentuk sebelum menjadi kata, yakni yang disebut morfem dengan segala bentuk dan jenisnya, perlu dibicarakan. Pembentukan kata meliputi pembicaraan mengenai komponen atau unsur pembentukan kata itu, yaitu morfem, baik morfem dasar maupun morfem afiks, dengan berbagai alat proses pembentukan kata itu, yaitu afiks dalam 
proses pembentukan kata melalui proses afiksasi, duplikasi ataupun pengulangan dalam proses pembentukan kata melalui proses reduplikasi, penggabungan dalam proses pembentukan kata melalui proses komposisi dan sebagainya. Jadi ujung dari proses morfologi adalah terbentuknya kata dalam bentuk dan makna sesuai dengan keperluan dalam satu tindak pertuturan.

Afiksasi merupakan salah satu proses morfologis yang paling sering ditemukan di dalam bahasa. Afiksasi atau pengimbuhan adalah proses pembentukan kata dengan mengimbuhkan afiks (imbuhan) pada bentuk dasar, baik bentuk dasar tunggal maupun kompleks. Afiksasi atau pengimbuhan sangat produktif dalam pembentukan kata, hal tersebut terjadi karena bahasa indonesia tergolong bahasa bersistem aglutinasi. Sistem aglutinasi adalah proses dalam pembentukan unsurunsurnya dilakukan dengan jalan menempelkan atau menambahkan unsur selainnya. Afiksasi atau pengimbuhan sangat produktif dalam pembentukan kata, hal tersebut terjadi karena bahasa indonesia tergolong bahasa bersistem aglutinasi. Sistem aglutinasi adalah proses dalam pembentukan unsur-unsurnya dilakukan dengan jalan menempelkan atau menambahkan unsur selainnya.

\section{METODE PENELITIAN}

Penelitian ini merupakan penelitian kualitatif. Teknik pengumpulan data yang digunakan adalah metode simak, teknik sadap, teknik simak libat cakap, teknik rekam, dan metode cakap. Penelitian ini akan dilaksanaan pada bulan September 2017 di Kampung Jengan Danum, Kecamatan Damai, Kabupaten Kutai Barat yang masyarakatnya merupakan pengguna asli bahasa Dayak Benuaq. Teknik analisis dalam penelitian ini menggunakan metode kajian distribusional. Dalam kajian morfologi digunakan beberapa model atau teknik dalam menganalisis satuan satuan morfologi, di antaranya teknik unsur bawah langsung (intermediated constituent) atau bagi unsur langsung (BUL).

\section{PEMBAHASAN}

Dalam bahasa Dayak Benuaq di Kampung Jengan Danum, Kecamatan Damai, Kabupaten Kutai Barat, terdapat tiga jenis afiks, yaitu: prefiks, sufiks, dan kombinasi afiks. Berikut ini akan dipaparkan analisis terhadap tiga jenis afiks yang ditemukan dalam Bahasa Dayak Benuaq di Kampung Jengan Danum, Kecamatan Damai, Kabupaten Kutai Barat tersebut, yang meliputi bentuk afiks, makna, dan fungsi akfiksasi.

Dalam bahasa Dayak Benuaq di Kampung Jengan Danum, Kecamatan Damai, Kabupaten Kutai Barat terdapat tiga jenis bentuk afiks, yaitu: prefiks, sufiks, dan berkolfiks (kombinasi afiks). Bentuk afiks pertama yang ditemukan adalah prefiks. Chaer (2015:23) menyatakan bahwa prefiks adalah afiks yang dibubuhkan pada kiri bentuk dasar. Dalam bahasa Dayak Benuaq di Kampung Jengan Danum bentuk prefiks yang ditemukan adalah $\{b e-\},\{p e-\},\{p e N-\}$, dan $\{t e-\}$.

Prefiks $\{b e-\}$ dalam bahasa Dayak Benuaq sering dijumpai penggunaannya pada kata: betokant, bebuek, bekubet dan bekulak yang bisa berbentuk kalimat perintah atau kalimat tanya misalnya pada kalimat Meq puq betokatn ko de? 'Apa sudah masakkah kamu tadi?' Bentuk prefiks \{be-\} dapat dilihat pada kata betokatn 'memasak' yang mempunyai makna sedang melakukan aktivitas dan berfungsi mengubah kategori kata seperti pada contoh yang semula adalah nomina okatn 'nasi' menjadi verba betokatn 'memasak nasi' dalam bahasa Dayak Benuaq prefiks $\{b e-\}$ mempunyai fungsi mengubah kategori kata yang semula nomina menjadi verba hampir serupa dengan prefiks \{ber-\} dalam bahasa Indonesia yang berfungsi mengubah kategori kata nomina menjadi verba. 
Prefiks \{pe- $\}$ dalam bahasa Dayak Benuaq jarang dapat ditemui karena penggunaannya sangat jarang. Hal ini disebabkan masyarakat suku Dayak Benuaq lebih sering menggunakan prefiks $\{p e N-\}$ dalam percakapan sehari hari. Namun hal ini bukan berarti prefiks $\{p e-\}$ tidak ada dalam bahasa Dayak Benuaq, hanya jarang ditemui. Hal ini terbukti pada penggunaan prefiks $\{p e-\}$ pada kalimat $O n$ bisa pekale ongan te sekolah aro? 'Kenapa dia bisa dipindahkan dari sekolah itu?' Bentuk prefiks $\{p e-\}$ dapat dilihat pada kata pekale 'dipindahkan' mempunyai makna menyatakan keterangan. Prefiks $\{\not e-\}$ mempunyai fungsi mengubah kata berkategori verba [kale] pindah menjadi adjektiva [pekale] pindahkan.

Prefiks \{peN-\} dalam bahasa Dayak Benuaq sering dijumpai penggunaannya, misalnya kata: penotek, penedap, penisep, penolak, penolum, penenyet, pengakant, dan penuke, yang biasanya dapat ditemukan pada kalimat pernyataan atau kalimat yang menyatakan perkerjaan. Prefiks \{pe-N\} pada kata penotek dalam kalimat Sayur ohoq epuk penotek keaq ohoq 'Sayur ini sudah dipotong seperti ini.' Pada kalimat tersebut terbukti prefiks $\{p e N-\}$ secara langsung menyatakan keterangan suatu tindakan yang telah dilakukan. Prefiks $\{p e N-\}$ pada analisis terebut mempunyai fungsi mengubah kategori kata seperti pada contoh yang semula berkategori verba [potek] menjadi adjektiva [penotek].

Prefiks $\{t e-\}$ dalam bahasa Dayak Benuaq sering dijumpai penggunaannya pada kata tetitur, teteak, dan tesaut, yang biasanya dapat ditemukan pada kalimat pernyataan atau menyatakan ketidaksengajaan. Prefiks $\{t e-\}$ pada kata teteak dalam kalimat Begamat atib teteak HP iro 'Hati-hati nanti terinjak HP itu' terbukti bahwa prefiks $\{t e-\}$ secara langsung menyatakan ketidaksengajaan atau sesuatu yang tidak sengaja terjadi. Prefiks $\{t e-\}$ berfungsi mengubah kategori kata berkategori verba [teak] menjadi adjektiva [teteak].
Selanjutnya, bentuk afiks lain yang ditemukannya adalah sufiks. Chaer (2015:23) berpendapat bahwa sufiks adalah afiks yang dibubuhkan pada akhir atau kanan bentuk dasar. Dalam bahasa Dayak Benuaq di Kampung Jengan Danum bentuk sufiks yang ditemukan adalah $\{-t n\}$. Sufiks $\{-t n\}$ dapat dijumpai pada kata edotn, entutn, okatn, lotutn, dan bototn. Misalnya pada kalimat Takaq dua endotn manan olo obok 'Kita dua jalan sendirian hari ini' terdapat kata bersufiks edotn. Kalimat tersebut secara tegas menyatakan kegiatan yang dilakukan hanya berdua saja. Sufiks $\{-t n\}$ dalam kalimat tersebut berfungsi mengubah kata berkategori verba [edoq] menjadi adjektiva [edotn].

Dalam bahasa Dayak Benuaq di Kampung Jengan Danum juga ditemukan kata berkonfiks (memiliki kombinasi afiks). Kata berkonfiks merupakan kata yang dibubuhi afiks pada kiri dan kanan kata dasar. Namun pembubuhan itu tidak sekaligus melainkan bertahap (Chaer, 2015:23). Kata berkombinasi afiks dalam Bahasa Dayak Benuaq misalnya kata dengan konfiks $\{k e-+N-\}$ misalnya pada kata kenaduk, kenencak, kenaduk, kenale, kenaput, kenatur, kenerasunt, kenobit, kenuhau, dan kenunci. Salah satu contoh kata tersebut terdapat pada kalimat iro sawoi dirak kenaduk ngank 'bubur itu harus diaduk terus.' Pada kalimat tersebut dapat kata berkonfiks $\left\{k e_{-}+N_{-}\right\}$yang memiliki makna tindakan atau perbuatan. Afiks berkonfiks/kombinasi afiks $\{k e-+N-\}$ mempunyai fungsi mengubah kategori kata yang semula verba [aduk] menjadi adjektiva [kenaduk]. Sedikit berbeda dengan fungsi dalam bahasa Indonesia karena perbendaharaan kata yang sedikit dan kesederhanaan bahasa.

Konfiks selanjutnya adalah $\{$ se- + $N-\}$. Dalam bahasa Dayak Benuaq terdapat pada kata senaok, senagur, senaut, senempaning, senemponak, seniau, seniot, senua, dan senuru. Salah satu contoh kata tersebut terdapat pada kalimat meq epuq senaut kukut 
yaq meraraq 'apakah sudah dicabut gigi yang sakit itu?' Afiks $\left\{s e_{-}+\mathrm{N}-\right\}$ mempunyai makna perbuatan atau tindakan. Afiks $\left\{s e_{-}+N_{-}\right\}$dalam bahasa Dayak Benuaq mempunyai fungsi mengubah kategori kata verba [saut] menjadi adjektiv [senaut. Sedikit berbeda dengan fungsi dalam bahasa Indonesia karena perbendaharaan kata yang sedikit dan kesederhanaan bahasa.

\section{E. PENUTUP}

Berdasarkan analisis yang telah dilakukan, dapat disimpulkan beberapa hal sebagai berikut. Pertama, bentuk afiks dalam bahasa Dayak Benuaq di Kampung Jengan Danum, Kecamatan Damai, Kabupaten Kutai Barat, meliputi prefiks, sufiks, dan kombinasi afiks (konfiks). Prefiks yang ditemukan, yaitu: $\{b e-\},\{p e-\}$, $\{p e N-\}$, dan $\{t e-\}$. Sufiks yang ditemukan, yaitu: $\{-\operatorname{tn}\}$. Sedangkan kombinasi afiks (konfiks) yang ditemukan, yaitu: $\{k e-+$ $N-\}$ dan $\{s e-+N-\}$. Kedua, makna yang muncul setelah pembubuhan afiks ke bentuk dasar dalam bahasa Dayak Benuaq di Kampung Jengan Danum, Kecamatan Damai, Kabupaten Kutai Barat, yaitu: menyatakan tindakan, menyatakan perbuatan, menyatakan akibat, menyatakan pekerjaan. Ketiga, fungsi afiks dalam bahasa Dayak Benuaq di Kampung Jengan Danum, Kecamatan Damai, Kabupaten Kutai Barat, yaitu: (a) mengubah kategori kata nomina menjadi verba; (b) mengubah kategori kata verba menjadi adjektiva; dan (c) mengubah kategori kata nomina menjadi adjektiva.

\section{DAFTAR PUSTAKA}

Chaer, A. (2014). Linguistik Umum. Jakarta: Rineka Cipta.

Chaer, A. (2015). Morfologi Bahasa Indonesia Pendekatan Proses. Jakarta: Rineka Cipta.

Dewi, W. W. R. (2009). Morfologi Bahasa Indonesia. Jakarta: Intan Pariwara.

Depdiknas. (2008). Kamus Besar Bahasa Indonesia (Edisi Keempat). Jakarta: Balai Pustaka.

Kridalaksana, H. (1996). Kamus Linguistik. Jakarta: Gramedia.

Mahsun. (2013). Metode Penelitian Bahasa. Jakarta: Raja Grafindo Persada.

Masnur, M. (2010). Tata Bentuk Bahasa Indonesia. Jakarta: Bumi Aksara.

Parera, D. J. (1990). Morfologi. Jakarta: Gramedia Pustaka Utama.

Ramlan. (2009). Morfologi: Suatu Timjauan Deskriptif. Yogyakarta: CV Karyono.

Marsono. (2011). Morfologi Bahasa Indonesia dan Nusantara. Yogyakarta: Gadjah Mada University Press.

Moleong, J. L. (2014). Metoologi Penelitian Kualitatif. Bandung: Remaja Rosdakarya. 
